\title{
Cartesian Egalitarianism: From Poullain de la Barre to Rancière
}

\author{
Devin Zane Shaw
}

\section{I. "a history or, if you prefer, a fable"}

Politics is a conflict over social rationalities or logics. This is one of the central claims of Jacques Rancière's political thought: the key rationality under dispute is an egalitarian logic, which is not a discussion of proofs and propositions, but rather the supposition of the equality of the intelligences and abilities of anyone and everyone. Politics takes place wherever there is a conflict between the logic of equality and the logic of policing, which is an inegalitarian distribution of bodies, places, tasks, and ways of speaking (Ranciere, Disagreement 29). The conflict of these two logics or rationalities (logoi) and practices is the basis of any set of social relations; every account of politics as speech or rationality $(\log o s)$ is also a count of what speech or rationality is: political conflict "forms an opposition between logics that count the parties and parts of the community in different ways" (Rancière, “Ten Theses" 35).

Thus it may seem surprising that Rancière explicitly links his account of political subjectification to René Descartes, to whom little political philosophy, let alone egalitarianism, is often attributed. In Disagreement, Rancière argues that:

Politics is a matter of subjects, or, rather, modes of subjectification. By subjectification I mean the production through a series of actions of a body and a capacity for enunciation not previously identifiable within a given field of experience, whose identification is thus part of the reconfiguration of the field of experience. Descartes's ego sum, ego existo is the prototype of such indissoluble subjects of a series of operations implying the 
production of a new field of experience. Any political subjectification holds to this formula. It is a nos sumus, nos existimus. (35-36)

Politics, for Rancière, turns on a transformation of what there is in common in social life, of what he calls the "distribution of the sensible" (partage du sensible): the ways in which bodies, places, practices, and visibilities are made intelligible within a historical situation. A political subject introduces within a given distribution of social relations new ways of being, doing, and speaking premised on the supposition of equality. But how does this relate to Descartes, with his "provisional moral code" (Discourse on the Method VI: 22-28), his general reluctance to engage socio-political questions, and his attempts to restrict the method of doubt to epistemological and metaphysical considerations (Meditations VII: 15)? What do Descartes' cogito and Rancière's dynamic of collective subjectification have in common?

I will argue that Rancière's thought is indebted to a specific tradition of Cartesian egalitarianism that runs from the often-neglected work of François Poullain de la Barre to Simone de Beauvoir. It is possible to identify three overarching features of this tradition. First, Cartesian egalitarianism thinks political agency as a practice of subjectivity, even if its proponents differ on how political practice is subjectively engaged (whether, for instance, this engagement begins with individuals or collectives). Second, Cartesian egalitarians share the supposition that there is an equality of intelligences and abilities shared by all human beings. This supposition follows from the beginning of Descartes' Discourse on the Method:

Good sense (bon sens) is the best distributed (partagée) thing in the world: for everyone thinks himself so well endowed with it that even those who are the hardest to please in everything else do not usually desire more of it than they possess. In this it is unlikely that everyone is mistaken. It indicates rather that the power of judging well and of distinguishing the true from the false - which is what we properly call "good sense" or "reason"-is naturally equal in all men, and consequently that the diversity of our opinions does not arise because some of us are more reasonable than others but solely 
because we direct our thoughts along different paths and do not attend to the same things. (VI: 1-2)

Looking past the ironic posturing of the first sentence, Cartesian egalitarians (such as Poullain de la Barre or Joseph Jacotot) take this "bon sens" as Descartes' fundamental idea: "there are not several manners of being intelligent, no distribution between two forms of intelligence, and then between two forms of humanity. The equality of intelligences is first the equality of intelligence itself in all of its operations" (Rancière, "L'actualité" 412-413, author's translation). ${ }^{1}$ The equality of intelligences has one other crucial consequence: if there is no hierarchy of intelligences, then there is no natural or inevitable hierarchy between those who "naturally" rule and those who are ruled.

Third, Cartesian egalitarians conceptualize politics as the processing of a wrong through the practice of dissensus. As Rancière writes, "politics becomes the argument of a basic wrong that ties in with some established dispute in the distribution of jobs, roles, and places," initiating "conflict over the very existence of something in common between those who have a part and those who have none" (Disagreement 35). Politics turns on who or what exists, or who or what counts, in common in society; it constitutes a new and more egalitarian distribution of the sensible. Dissensus produces conflict because the logic of policing counts the parts of society as parties with specific interests that can be represented according to customary forms of intelligibility, with no possibility that there would be a void or supplement to society, a part which has no part which is not represented (“Ten Theses" 36). For Rancière, politics takes place when a "part of those who have no part" (la part des sans-part) contests the policing of social relations and conventions in order to introduce new ways of speaking, being, or doing. 
In this essay, I will examine how these three features of Cartesian egalitarianism emerge from the work of Descartes. Although he makes subjectivity (as cogito) and intellectual equality central components of his philosophy, Descartes nevertheless limits his critique of the prejudices of intellect, authority, and habit to the epistemo-metaphysical problem of separation. After reconstructing how egalitarianism functions in Descartes' system, I will show how Poullain reconceptualizes the problematic of separation in a socio-political context, transforming it into the problem of a wrong. He uses Descartes' dualism to show that there are no natural qualities of the mind or the body that can justify the inequality of the sexes. Women have been wronged, Poullain argues, because there are no clear and distinct reasons for their subjugation. Instead, women have been denied the full capacity for the exercise of their reason due to the political self-interest of men and the force of social convention.

After examining Descartes and Poullain, I will shift the discussion to the philosophy of Beauvoir. Though this has the unfortunate effect of setting aside many other developments in the historical relationship between Cartesianism, egalitarianism, and feminism, Beauvoir's conception of the relationship between political subjectivity and the processing of a wrong foreshadows several of Rancière's concerns. ${ }^{2}$ I will argue that Beauvoir's account of a wrongwhich occurs, for instance, when a woman is forced to assume, and thus limit, her freedom as an "other" rather than a "subject" — marks a significant advance over Sartre's individualist ethics of the 1940s. Because Beauvoir focuses on those whose agency has been historically marginalized, her account of political subjectivity avoids the pitfalls that have so often plagued many strains of Marxism, which amplify the teleological character of the proletariat's historic mission. For Beauvoir, it is not possible to subordinate one struggle to another; a historic mission, as it were, 
can only be built out of practices of solidarity, and not out of the hierarchization of demands, abilities, and intelligences.

Thus I focus on Beauvoir because her Cartesian egalitarianism is an important precedent to Rancière's. Because Rancière does not, to my knowledge, extensively discuss the work of either Poullain or Beauvoir, I do not intend this as an explication of Rancière's work, but rather as "a history or, if you prefer, a fable" (Discourse VI: 4) that provides an overview of a longer tradition of egalitarianism than is typically acknowledged. I will conclude by showing, through a brief reading of his book The Ignorant Schoolmaster, how Rancière's understanding of Cartesianism emphasizes the egalitarianism of Poullain and Beauvoir rather than Descartes' metaphysical or epistemological commitments.

\section{Egalitarianism and Separation}

We do not typically consider Descartes an egalitarian. He is more often interpreted, in the post-Heideggerian tradition of philosophy, as an epochal figure of the modern destiny of metaphysics. On this account, Descartes introduces the metaphysical ground of technicity by dividing all beings between thinking subjects and objects of a calculable objective world. ${ }^{3}$ Or, following Antonio Negri, he is considered an architect of a "reasonable ideology" that expresses the class compromise constitutive of the formation of bourgeois class power after the 1620s: whereas Descartes formulates his philosophy as the production of human significance (and practical utility) in its separation from the world, the bourgeoisie affirms its position in civil society at the same time that it accepts a temporary class compromise with absolutism (Negri 295-296). 
Recently, however, several prominent radical thinkers have laid claim to the legacy of the Cartesian subject. For example, Alain Badiou, Rancière, and Slavoj Žižek all hold that the emergence of subjectivity in political praxis is irreducible to the reconfiguration of Cartesian thought as instrumental rationality, whether it is considered as a moment of technological enframing or as a moment of bourgeois compromise. ${ }^{4}$ Yet the Cartesianism of Badiou and Žižek does not imply the supposition of equality. Instead, their commitment is largely programmatic. Žižek, in The Ticklish Subject, proposes that the Cartesian subject is a revolutionary alternative to what he considers to be the hegemony of a "liberal-democratic multiculturalism" that ranges indiscriminately from new age obscurantism to postmodern deconstruction (1-4). For Badiou, Descartes is a paradigmatic materialist dialectician, insofar as he maintains that truths are eternal against the general presumptions of "democratic materialism," which counts only bodies and languages, and Nietzsche's and Heidegger's "aristocratic idealism," which, despite its overwhelming sense of resignation, aims to preserve the poetic event against modern nihilism (Logics of Worlds 1-6).

In contrast to these interpretations, I will argue that Descartes' work wavers between egalitarianism and the constraints of method. On the one hand, the Cartesian project, even for Descartes, requires the supposition of equality in order for its method to be persuasive. That is, rather than appealing to tradition, convention, or authority to establish the validity of his system, Descartes calls for the well-considered and reasonable judgments of his readers. And yet, on the other hand, Descartes makes persistent appeal to the necessity of method to prevent the egalitarianism of his address from encouraging a thoroughgoing critique of all social conventions. Instead, his system is redirected toward epistemological and metaphysical questions, which are structured by the problem of separation. 
Let us begin with Descartes' supposition of equality. Despite his program of searching out the self-foundational moment of a system, his philosophy is nevertheless conditioned (but not necessarily determined) by its historical situation, or its distribution of the sensible. When Rancière speaks of a distribution of the sensible, it includes the relations between subjects, objects, and places, and the ways of speaking, doing, and being that make these relations intelligible. While policing, in Rancière's terms, is a process of hierarchically arranging these relations and enforcing them, we should not consider a distribution of the sensible as static until politics intervenes; instead, the intelligibility of these relations is also a dynamic, which can itself change, enter into periods of stability, and undergo crises from which a politics of dissensus can emerge (or not).

Though it is not a moment of politics in Rancière's sense, Descartes' thought inaugurates a new way of thinking the relations between subjectivity, habit, and intelligibility within an intellectual milieu in transition, in which Scholasticism and Renaissance philosophy have been challenged by a renewed sense of skepticism. This conjuncture is not unique to philosophy, but is itself enmeshed within a series of socio-political upheavals. Negri, for instance, points to the recomposition of class power after the European economic crisis of 1619-1622 and the condemnation of Galileo (112-126; 140-155). In addition, the renewal of skepticism is not only of philosophical interest, but also an expression of the "epistemological implications of cultural difference" brought on by advances in European techniques of travel (to, for instance, China), and the conquest of the Americas (Bordo 40-41). Take, for example, Montaigne's remark that "each man calls barbarism whatever is not his own practice ... indeed it seems that we have no other test of truth and reason than the example and pattern of the opinions and customs of the country we live in" (quoted in Bordo 41). 
In the Discourse, Descartes makes a similar remark: "It is good to know something of the customs of various peoples, so that we may judge our own more soundly and not think that everything contrary to our own ways is ridiculous and against reason (contre raison), as those who have seen nothing of the world ordinarily do" (VI: 6 , translation modified). ${ }^{5}$ He draws two conclusions from this diversity of customs: first, "not to believe too firmly anything of which I had been persuaded only by example and custom" (VI: 10), and second, that the knowledge of cultural difference helps justify the supposition that opens the Discourse, that good sense or reason is "naturally equal in all men" (VI: 2) ${ }^{6}$ From these two conclusions Descartes proposes a new relationship between subjectivity, habituation, and intelligibility. This new relationship is founded on the cogito or thinking being, which emerges from a method of doubt directed toward habits or practices derived from custom and a discourse of intelligibility established on the authority of the schools. The significance of this critique of convention turns on whether it is conceived as a project of intellectual emancipation, or as the metaphysical and epistemological problem of separation.

It is possible, beginning with the Discourse, to read Descartes' project as an exercise in intellectual emancipation. Starting from the premise of the equality of intelligences and abilities, Descartes delineates his method of directing his reason as an example of "self-instruction" for the reader to judge as to whether it is a worthy example for imitation or improvement (VI: 4). It is not a necessary order of reasons, as it is in the Meditations, or an attempt at "teaching," but an account of how Descartes had "tried to direct [his] own" reason (VI: 4). By stressing the egalitarian aspect of this work, we can see that the validity of the subject as thinking being is verified by the capacity for the direction of reason to be repeated through each reader's selfinstruction. The emergence of the cogito transfers authority from the customs of the schools to 
all those to whom reason or good sense is distributed - a lesson in the practice of thinking learned from Descartes' travels rather than the schools (VI: 5-6). The intelligibility of the new philosophy — and its foundation, the cogito — is verified through the free use of the reader's own reason, rather than doctrinal authority.

Nevertheless, the socio-political consequences and the gestures toward a broader vernacular culture are absent from the Meditations. The contingent emergence of the cogito as a response to a crisis in intellectual authority within the sciences is instead given a metaphysically necessary status, and philosophical inquiry becomes a problem of ascertaining the proper epistemological and metaphysical foundations for physics. The egalitarian moment of the Discourse is now restricted to the problem of the separation of self and world. ${ }^{7}$ Once we enter into the order of reasons of the Meditations, the situation becomes, as Sartre argues, that of "the autonomous thought which discovers by its own forces intelligible relations between already existing essences" (La liberté cartésienne 289, author's translation). ${ }^{8}$

Let us look at the way that the Meditations recasts the relationship of subjectivity, habit, and intelligibility. The "First Meditation" begins with Descartes's acknowledgement that he has been accustomed since childhood to a method of making judgments that has led to numerous falsehoods, which leads him to suspect that the basis of those judgments_-information "acquired either from the senses or through the senses"-is doubtful (VII: 18). This passage carries a double significance. In fact, Descartes wavers between two different accounts of the basis of the judgments he has discovered to be doubtful. Both share the same starting point - the prejudice of relying on the senses has a basis in the habits acquired in childhood-but they differ on how these habits are acquired. One, which I will call the "prison of the body" account, identifies the body as the cause of the prejudices that prevent the proper use of reason. ${ }^{9}$ In the subsequent 
history of Cartesian egalitarianism, this metaphysical account of the origin of prejudices is rejected in favor of the second account, which focuses on the socio-political critique of conventions, such as criticisms of Scholasticism.

In the Discourse, we find a socio-political critique of the prejudices of childhood. One accepts teaching based on authority and explication, rather than according to reason. Descartes recounts that from "my childhood I have been nourished upon letters, and ... I was persuaded that by their means one could acquire a clear and certain knowledge of all that is useful in life" (VI: 4). Books — "letters"— - had taught him the basic premise of Scholastic philosophy, that "nihil est in intellectu nisi prius fuerit in sensu," that "nothing is in the intellect unless it was first in the senses" (Carriero 12ff). Rather than understanding the immediacy and intelligibility of the sensible as a naïve standpoint, we could understand it as a product of a determinate (and by Descartes' time, reified) historical production of knowledge, that is, of Scholasticism. In this case, the method of doubt and the emergence of the cogito subject become a challenge to one particular historical system of knowledge, but a persistent vigilance is required to prevent Descartes' thought from being reified into a teaching based on authority, a vigilance evidenced by his repeated references to needing to inculcate new habits of thought against the lures of custom. This is how, broadly speaking, the Cartesian egalitarians will take up his thought.

On the other hand, Descartes also faults the body itself for propagating the habits and prejudices of childhood; the body is, on this account, the prison of the soul. ${ }^{10}$ In the Principles of Philosophy, Descartes writes:

In our childhood the mind was so immersed in the body that although there was much that it perceived clearly, it never perceived anything distinctly. But in spite of this the mind made judgments about many things, and this is the origin of the many preconceived opinions which most of us never subsequently abandon. (VIIIa: 22) 
On this account, Scholasticism's reliance on the senses as the foundation of knowledge serves to reinforce the prejudices of the body. The task for thinking, for Descartes, is to obtain through the method of doubt a reflexive distance from what we take to be the immediacy of the senses to allow the intellect to mediate our judgments. The task is to separate thinking substance, the cogito, from the mechanisms of the body through a method that makes it possible to discover clear and distinct ideas of "already existing essences," as Sartre puts it—of, for instance, thought, extension, substance, and God (La liberté cartésienne 289, author's translation). Of course, as many commentators have pointed out, it is difficult to see how Descartes can establish a measure to test the truth of a judgment after the introduction of hyperbolic doubt. Even if he can demonstrate the truth of the cogito as a thinking being, it is still possible that he is being deceived about other kinds of knowledge. To overcome the evil genius hypothesis, Descartes proceeds in the "Third Meditation" to attempt a proof of his dependence on a supremely perfect being. This supremely perfect being functions, in the system, as the guarantor of the knowledge that Descartes establishes throughout the rest of the Meditations, gradually returning into his grasp the fields of mathematics, physics, and everyday sense experience (as long as these things are conceived "clearly and distinctly"). With thought and extension clearly and distinctly separated, and with their correspondence guaranteed by God, the reconstruction of philosophy from the cogito allows Descartes to introduce a physics that explains bodies and movements according to the general rules of mechanics and mathematics, rather than the Scholastic —or childlike (Descartes, "Sixth Set of Replies" VII: 437-439) - cognition of universals from particular qualities derived from the senses (see Carriero 16-17; Garber 84-88). By establishing the "already existing" essential validity of the separation of thought and extension, Descartes 
limits the possibility that doubt toward the sensible could open into a socio-historical critiquethat is, that knowledge could be historically situated.

Instead, Descartes suggests that Scholasticism lends the errors of the body an artificial veneer of rationality. In the unfinished dialogue "The Search for Truth," Descartes juxtaposes the "natural" use of reason to the "artifice" of Scholasticism. In this text, the greatest threat to knowledge is not the separation of thought and extension and of self and world, because in his system God guarantees that they have an intelligible relationship; the greatest threat is that the good sense of the meditator is captured by the artifice of authority and the schools, that, as in the case of Epistemon the Scholastic, one is lulled into the "habit of yielding to authority rather than lending [one's] ear to the dictates of reason" (X: 523). ${ }^{11}$ By contrast, Descartes claims that his method begins, through the use of doubt, by inculcating "a judgment which is not corrupted by any false beliefs and a reason which retains all the purity of its nature" (X: 498). The whole rhetorical staging of "The Search for Truth" relies on Eudoxus being able to direct Polyander (a character who has never studied but possesses "a moderate amount of good sense") in this "natural" use of his reason with the aim of discovering the true principles of (Cartesian) philosophy (X: 514). Yet if Cartesianism lays claim to being the "natural" use of reason, then it risks, despite Descartes' protests that he is not attempting to "teach" anyone, repeating the problems that he had identified with Scholasticism: the naturalization of doctrine through the reification of a historically situated knowledge. In Rancière's terms, the intellectual emancipation promised by the Cartesian "ego sum, ego existo" is subordinated to the intellectual policing of method. 


\section{The Rationality of a Wrong}

The social and political consequences of Descartes' thought were not lost on his contemporaries, especially in the conflicts over the equality of the sexes. ${ }^{12}$ His account of the egalitarian distribution of reason stands in stark contrast with the Aristotelianism of the Scholastics. Though Aristotle argues that the possession (hexis) of logos (speech and reason) is unique to human animals, implying a universal capacity, he nevertheless proceeds to exclude some humans from this capacity. So while the logos and an aisthesis of justice, the useful, or the good, may be shared (Politics 1253a9-18), this logos is not possessed by all. A slave, Aristotle argues, is he who "by nature" apprehends (aisthesis) speech but does not possess (hexis) it (1254b24-25). Women are similarly dispossessed of reason. At the beginning of the Politics, Aristotle claims that women are made only for the purpose of the reproduction of the species and so are inferior to men. Later, he argues that women are free (1259a40) but are incapable of ruling, for just as the rational part of the soul rules over the irrational, so does a man rule over a woman — who possesses reason without authority (1260a14).

Poullain de la Barre appropriates Cartesian philosophy to show, in contrast to Aristotle, that patriarchal social forms possess authority without reason. In his On the Equality of the Two Sexes, Poullain notes that:

if something is well established, then we think it must be right. Since we think that reason plays a role in everything men do, most people cannot imagine that reason was not consulted in the setting up of practices that are so universally accepted, and we imagine that reason and prudence dictated them. (54)

Using the results of Cartesian philosophy, Poullain argues that the inequality of the sexes-that is, the subjugation of women - is founded on prejudices of habit and custom, and political selfinterest rather than well-founded reasons. Though we have seen that Descartes restricts his 
system to the epistemological and metaphysical problem of separation, Poullain uses Cartesian philosophy to conceptualize the wrong at the basis of the inequality of the sexes: both popular opinion and scholarly learning dispossess women of subjectivity and the capacity to reason. Poullain's task, then, is to demonstrate how the part of those who have no part-women as they are socially excluded and subjugated — can lay claim to a political subjectivity that they have been denied. This claim begins with undermining the foundations of long-standing prejudices that justify inequality. This process of critique can open the possibility of a more egalitarian distribution of the sensible, in which women are recognized as thinking and speaking subjects, not merely passive objects of men's possession, and as agents who are just as able as men to make public use of their reason.

In On the Equality of the Two Sexes, Poullain argues (in a passage that later appears in paraphrase as an epigram to The Second Sex) that the historical and intellectual record shows that:

Women were judged in former times as they are today and with as little reason, so whatever men say about them should be suspect as they are both judges and defendants. Even if the charges brought against them are backed by the opinions of a thousand authors, the entire brief should be taken as a chronicle of prejudice and error. (76)

To overturn these judgments, Poullain criticizes both "popular" and "learned" prejudices against women. There are, he argues, no natural reasons for the "chronicle of prejudice and error," but only the "reason" of political self-interest. The oppression of women has been enforced by the physical strength of men, and policed by naturalizing a gendered division of labor within the distinction of public and private domains (see his "historical conjectures" at 56-60). This situation is reproduced, he argues, when in both ancient and modern times intellectuals have 
generally taken "their prejudices with them into the Schools" and worked to give reasons for the subjugation of women (79).

Poullain reconceptualizes Descartes' distinction between thought and the body to show that there are neither intellectual nor physical inequalities between men and women. Customary prejudice, he notes, holds that women cannot exercise reason as well as men, often pointing out how women are more passionate or intemperate, how their use of reason is less detached from the body. Poullain turns this argument around to claim that those who maintain this customary prejudice have themselves provided reasons that do not consider the faculties of the mind independently from the body. For, he claims, given that thought is a substance other than body, the mind has no sex, and if the mind has no sex, good sense or reason is equally distributed to both men and women. Moreover, if equality is the case, there is no natural basis for an intellectual division of labor. From the standpoint of well-considered reasons, antifeminists have confused nature and custom: the perceived intellectual flaws of women are the product of a lack of education. In addition, the intellectual stultification of women, Poullain notes, also has a political basis: those who deny that the "scope of reason is boundless and has the same influence over all people" do so out of self-interest, fearing that ending a gender- (and class-) based intellectual division of labor will devalue the prestige and authority that comes with learning (95). Given the numerous prejudices of intellectuals, Poullain even suggests that the exclusion of women from education could work to their eventual advantage because they would be able to direct their natural reason without the artifice of the schools (62-65). ${ }^{13}$

That the mind has no sex, and that good sense or reason is equally distributed among all humans, are the positions of Poullain that are closest to Descartes. It is more difficult to use the Cartesian system to establish that inequality is not based on embodied differences, given that 
Descartes sometimes argues that the body is the prison of the soul, that the confusions of the body produce many of our prejudices. The stakes are also elevated when one considers that the authoritative figures of Scholastic philosophy viewed the capacities of the body with some disgust - especially when it comes to women's bodies. Women were considered "monstrous" by Aristotle and considered "imperfect" or "incomplete" men by others (Poullain 118). ${ }^{14}$ Poullain, then, cannot rely on Descartes' claim that the body is the origin of human prejudices about the world to show that there are no natural inequalities that can be discovered in the embodied differences between men and women.

Instead, Poullain, like several other Cartesians and Cartésiennes, attempts to rehabilitate the body within the Cartesian system. ${ }^{15}$ He argues that the reproductive functions are the only embodied differences between men and women; in all other ways the mechanisms of the body follow the same laws (82). Poullain emphasizes Descartes' Passions of the Soul over his "prison of the body" conjectures. ${ }^{16}$ In addition, embodied differences are not considered imperfections. ${ }^{17}$ Instead, Poullain claims that "God desired" to create the difference of the sexes so that human beings would be dependent upon each other, and that each body is "perfect in its own way: both are presently constituted as they were intended" (104). This position, however, valorizes motherhood in a way that later feminists such as Beauvoir would openly challenge. Despite his precautions in other arguments, Poullain seems to rely on the assumption (especially given that he attributes it to "God's desire") that maternity is a natural good that provides women with "the highest purpose in the world, namely to bear us and nourish us in their womb" (104). Nevertheless, these arguments for the equality of two kinds of "perfect" bodies contrast starkly with the depreciations of the body current during the seventeenth century. Despite the contingencies of his historical situation, Poullain's philosophy is a prototype for an emancipatory 
political thought that seeks to show both how all humans are capable of exercising their freedom, and how, as Beauvoir will write three centuries later, biology is not destiny.

\section{Woman as Other, Woman as Subject}

As is well-known, both Sartre and Beauvoir take the cogito as a starting point for interrogating the freedom of human being. In Beauvoir's words, the "Cartesian cogito expresses both the most individual experience and the most objective truth" insofar as it affirms that human freedom is the basis of all values (Ethics of Ambiguity 17). This much Sartre and Beauvoir have in common, but they diverge concerning how these values can be realized within the social life of the individual. Through the mid-1940s, Sartre remains focused on the problem of how an individual can act freely within a historical situation that is not of his or her own making, and many of his more hyperbolic comments imply that, as long as one is not in bad faith, all choices are equivalent as long as they are free. ${ }^{18}$

For Beauvoir it is necessary that practices of freedom and the situations that they transform be understood as historically differentiated, so neither situations nor choices are equivalent. This requires Beauvoir to move from an individualist ethics to conceptualizing these concerns from their bases in social perceptions and relations (see Simon 41-54). In The Second Sex, Beauvoir reconceptualizes the question of subjectivity as a political problem, not just in the sense that she examines how a subject assumes her freedom within a historical situation, but also insofar as this question turns on what we have called a wrong: she pursues the consequences of the fact that, despite being an "autonomous freedom," a woman "discovers and chooses herself in a world where men force her to assume herself as Other" (Second Sex 17). Like Poullain, Beauvoir rejects the thesis that there are biological data that necessarily determine, and form the 
"fixed destiny" of, the subjugation of women within the social hierarchy of the sexes (44). Instead, she argues that all situations are politically and historically conditioned, meaning that all possible biological data take on social values rather than intrinsically natural values that transcend a given situation. ${ }^{19}$

Beauvoir therefore turns to the investigation of the historical and political bases of the inequality of those who are able to assume their subjective freedom, and those who-depending on the situation, could be women, African Americans, the colonized, and other groups - confront a historical situation in which they are considered pejoratively as "others." It is a fundamental supposition of existentialism that all human beings have the capacity to exercise their freedom, because freedom is the basis of all social values, and yet in each situation they cannot exercise the full extent of their freedom.

Beauvoir politicizes the existentialist account of subjectivity and freedom by conceptualizing how a wrong is introduced into social distinctions between subjectivity and alterity. This wrong occurs because women are constrained by a situation in which men are subjects, and women are others. The distinction between self (or subject) and other, she notes, is not necessarily the basis of a wrong. The category of the other "is as original as consciousness itself" (6). Following Lévi-Strauss, Beauvoir states that the distinction between self and other can designate a relationship of reciprocity (such as that between nature and culture) or opposition and antagonism (between, for instance, two different cultures). But it is quite possible that the well-traveled person can recognize the reciprocity of these two different cultures, which relativizes their concept of alterity—just as Descartes noted that visiting others can reveal how one's own customs are just as arbitrary and locally determined as another's. In such a situation, 
alterity is not a negative category, but one through which one's own values are questioned and reconsidered.

What is different about the situation of women is that the distinction between men and women carries with it a series of value-laden social judgments: a woman is defined against the standard of man and the man's attributes are given positive values, while women's attributes are considered negatively as flaws or insufficiencies. These values are reinforced because men arrogate to themselves the sole capacity to make such judgments. As Kail writes, women are interpellated in "a specific regime of alterity [that] shows that rulers control the meaning of the situation by setting the very conditions that make relationships possible" (157). Beauvoir produces numerous examples to show how, in such situations, "Humanity is male, and man defines woman, not in herself, but in relation to himself; she is not considered an autonomous being" (Second Sex 5). This situation is prevalent in both social and intellectual life. Take, for instance, Lévinas' account of one's responsibility toward a transcendent Other: Beauvoir sardonically notes that his claim that "alterity is accomplished in the feminine" forgets that a “woman also is consciousness for herself" $(6$, footnote).

Although much of The Second Sex is dedicated to diagnosing and cataloguing how a woman is defined against a masculine standard, Beauvoir also points toward the possibilities of women's emancipation. These possibilities can help us understand how the relationship of subject and other can give rise to a politics that challenges a wrong. First, a wrong occurs if the other's freedom is denied, such as when so-called feminine values - like the myth of the "Eternal Feminine" - are created or upheld by men and utilized to police the "proper" places or practices for a woman. For Beauvoir, it is not enough to attempt to reverse the polarity of value-laden terms. ${ }^{20}$ Instead, reciprocity must be introduced into the free creation of social values. 
Second, Beauvoir's politics are universal and egalitarian. She argues that the social hierarchization of recognizing some people as subjects and some people as others is the fundamental basis of inequality. Be it the distinction between men and women, Americans of European descent and African Americans, or the bourgeoisie and the proletariat, "whether it is race, caste, class, or sex reduced to an inferior condition, the justification process is the same" (12). This serves as a reminder that in each case those who rule attempt to demonstrate that there is some natural reason for inequality. Thus a crucial task for politics is to demonstrate that these so-called natural differences are based on social relations. But the dual lesson of Beauvoir's critique of Marxian economism must not be forgotten. First, all struggles emerge from, and are conditioned by, their local and historical situation, which means that they use varied approaches to emancipatory practices. Hence second, the emancipatory aspirations of a people cannot be subordinated to another group's aspirations. One cannot then argue that the historical mission of the proletariat requires that, for instance, women subordinate their demands and practices to those of the proletariat. (Despite the rejection of a teleological concept of historical struggle, one should nevertheless maintain, like Beauvoir, that women's liberation requires the end of their economic exploitation). These various struggles can only be strengthened and reinforced by what Beauvoir calls "reciprocity"-by practices of solidarity that do not reproduce the social hierarchies that these groups are combating.

While Sartre's existential appropriation of the cogito marks him as a Cartesian, Beauvoir is a Cartesian egalitarian. Her conceptualization of political subjectivity follows Descartes and Poullain insofar as it affirms that reason or good sense is equally distributed to all people-far from a world of sovereign subjects and their inferiors, she proposes a political program that instills the reciprocity of practices of freedom. Her existentialism begins with the individual, but 
it demands that the individual aims toward accomplishing practices of reciprocity and freedom that expand "toward an open future" (16).

\section{Toward Collective Egalitarianism}

This history or fable of the egalitarianism that leads from Descartes to Beauvoir shows that "Cartesianism" cannot be reduced to several of its more prominent conceptual commitments, such as mind-body dualism, the technicity of its mechanistic physics, or even, as we will see with Rancière's critique, the so-called rigors of the method. Cartesianism is also defined by its egalitarianism: the formation of a political subject from the supposition of the equality of intelligences. This subject is political insofar as its praxis turns on the processing of a wrong, an egalitarian challenge to the inequalities of any social order. As we have seen, Cartesianism from Poullain to Beauvoir constitutes a direct challenge to the claim that there is a hierarchy of intelligences.

If egalitarianism is a key component of this kind of Cartesianism, then it becomes possible to see why Rancière argues, in Disagreement, that "Descartes's ego sum, ego existo is the prototype of such indissoluble subjects of a series of operations implying the production of a new field of experience" (35). This new field of experience-what we could call, following Beauvoir, the collective reciprocity of equality-is opened when the part of those who have no part engage in political practice, challenging a social distribution that counts them as inferiors or subordinates, such as the count, challenged by Poullain and Beauvoir, that women are others and not subjects of freedom. Without this aspect, it is difficult to see why Rancière lays claim to the Cartesian legacy, for he directly challenges, through a discussion of Joseph Jacotot, many of Descartes' epistemological and metaphysical assumptions. 
In fact, Rancière's work does not contain an extensive interrogation of Descartes' work. In an epigram to The Philosopher and His Poor, Rancière reproduces from Baillet's Vie de Monsieur Descartes an account of the friendship between Dirk Rembrantsz, a Dutch peasant shoemaker and autodidact astronomer, and Descartes, in which Descartes embraces a man of lower social standing because of their common interest in astronomy (xxii-xxiii). Baillet's story provides a counterpoint to the ways - criticized by Rancière - in which Plato, Marx, Sartre, and Bourdieu treat the poor in their respective philosophies. ${ }^{21}$ Nevertheless, this epigram only hints at the problematic of egalitarianism that Rancière will develop more extensively in The Ignorant Schoolmaster, where Descartes intermittently emerges from the shadows of Joseph Jacotot. There Rancière contrasts the emancipatory teachings of Jacotot to the stultification of the teachings of the "Old Master," whose primary function is to explicate knowledge to those who do not possess it. Jacotot presents - or, perhaps, discovers - a method of teaching that emphasizes the equality and reciprocity of intelligences, and thus realizes that the pedagogue must teach that he or she has no expertise to teach (15). Rather than transmission and expertise, the ignorant schoolmaster interrogates and verifies that the student is attentive (29). Rancière argues that the division of labor between the "Old Master" and the family, between instruction and moral teaching, reinforces social order: the student draws from science what is not his own, and he draws from moral education what his place is (35). Using a free indirect style that quotes Jacotot, Rancière writes:

Emancipation is precisely the opposite of this; it is each man becoming conscious of his nature as an intellectual subject; it is the Cartesian formula of equality read backwards. "Descartes said 'I think, therefore I am'; and this noble thought of the great philosopher is one of the principles of universal teaching. We turn this thought around and say: 'I am a man, therefore I think." The reversal equates "man" with cogito. Thought is not an attribute of the thinking substance; it is an attribute of humanity. (35-36) 
Jacotot, for Rancière, turns Cartesian thought around twice. The Cartesian egalitarianism, as it were, of Jacotot, privileges the supposition of equality that begins the Discourse on the Method: given that reason is equally distributed to all, each meditator thinks. Hence there is no hierarchy of intelligences, and each human activity "is the practice of the same intellectual potential" (36). In addition, the equation of "man" and "cogito" is telling. As we know, after the cogito is demonstrated in the "Second Meditation," Descartes rejects the inference that the cogito is a "man" or "rational animal" (VII: 25-26). For Rancière, however, metaphysical commitments are less important than the supposition of equality; to say "ego sum, ego existo" is the initiation of a new field of experience for speaking beings, rather than one step in an orderly method. Method, Rancière argues, is one way to constrain the equality of intelligences, by ranking one's capacity for inquiry by setting out a series of steps that must be duplicated, lest the student go astray. Thus Jacotot and Rancière introduce a second turn of Cartesian thought by rejecting the method.

Following Jacotot, Rancière argues that once the supposition of equality is accepted, emancipation can begin from anything that individuals have in common. For Rancière, this supposition is not just a concern of pedagogy, but of politics itself. To underline the Cartesian import of this supposition, let us look at another intellectual source for his concept of a wrong. It is without doubt that this concept is in part derived from the young Marx's account of the proletariat: the proletariat has a universal character because its revolution marks the dissolution of all classes when it overthrows the bourgeoisie which has perpetrated an "unqualified wrong" in its oppression of all other classes (38; compare to Disagreement 18). Yet there is a tendency within Marxism that subordinates all other "particular wrongs" of others (women, anti-colonial struggles) to the historico-teleological mission of the proletariat, and this tendency is explicitly rejected by Cartesian egalitarians such as Beauvoir or Rancière, who argue that emancipatory 
struggles cannot be subordinated to one another, but must be reinforced through solidarity, by whatever they have in common.

A Marxist analysis would certainly note that Cartesianism in general stakes its validity on an individual's perception of the social world and an individual's practice. Rancière (like Beauvoir before him) sees the limitations of individualism, and that is why he transforms the subjective ego sum, ego existo into the reciprocity of the nos sumus, nos existimus, with the latter designating a new field of collective political practice. But the Cartesian "prototype" has two positive aspects. First, like Marx, as I have argued above, Poullain and Beauvoir conceptualize politics as the processing of a wrong. But second, and in contrast to the teleological tendencies of Marxism, there is no privileged subject, no finality that drives history, but only the persistently renewed struggle against all forms of social inequality. Emancipation is not an end point of a historical continuum. Instead, emancipation is only possible through the efforts of those who combat inequality and oppression through practices of reciprocity and solidarity. In this sense, Rancière is a Cartesian egalitarian.

\section{Notes}

1 “... il n'y a pas plusieurs manières d'être intelligent, pas de partage entre deux formes d'intelligence, donc entre deux formes d'humanité. L'égalité des intelligences est d'abord égalité à soi de l'intelligence dans toutes ses opérations."

2 For accounts of the relationship between Cartesianism, egalitarianism, and feminism, see Atherton, Harth, Rodis-Lewis, and with discussions of Poullain's predecessors, Delon and Stuurman 52-86. Atherton argues that seventeenth century feminism was motivated in part by "the concept of reason that could be found in Descartes" rather than, as later feminism would be, by "any general beliefs about equal human rights" (20).

${ }^{3}$ Heidegger claims that "Descartes does not doubt because he is a skeptic; rather, he must become a doubter because he posits the mathematical as the absolute ground and seeks for all 
knowledge a foundation that will be in accord with it" (What is a Thing? 103). This foundation, of course, is the cogito.

4 Badiou argues that a Marxism "sutured" to the scientific condition of philosophy (read: Althusser) dovetails theoretically with Heidegger when it reduces the subject to "a simple operator of bourgeois ideology." The scientific Marxist, then, would say: "for Heidegger, 'subject' is a secondary elaboration of the reign of technology, but we can see eye to eye if this reign is in fact also the bourgeoisie's" (Manifesto for Philosophy 92). It should be noted that Negri is more ambivalent than Badiou's typical "scientific Marxist"; he seems to admire the revolutionary character of Descartes' thought even if he reproaches what he sees as its fundamental compromise.

${ }^{5}$ Later in the Discourse, Descartes writes: "I have recognized through my travels that those with views quite contrary to ours are not on that account barbarians or savages, but that many of them make use of reason as much or more than we do" (VI: 16).

${ }^{6}$ Aimé Césaire, in his Discourse on Colonialism, invokes the principles of Cartesianism against the false universality of the colonial legacy (its science, politics, and sociology), which denigrates the non-European to the benefit and "glory" of Western bourgeois society. He argues that 'the psychologists, sociologists et al., their views on 'primitivism,' their rigged investigations, their self-serving generalizations, their tendentious speculations, their insistence on the marginal, 'separate' character of non-whites," rest on "their barbaric repudiation, for the sake of the cause, of Descartes's statement, the charter of universalism, that 'reason ... is found whole and entire in each man,' and that 'where individuals of the same species are concerned, there may be degrees in respect of their accidental qualities, but not in respect of their forms, or natures"” (56).

${ }^{7}$ This egalitarianism would also be troubled by the exclusion of the figure of madness from the valid and considered reasons for doubt. Even Descartes' correction of Arnauld - the reason of madmen is not "extinguished" but "disturbed" ("Fourth Set of Replies" VII: 228)—will not ameliorate this exclusion (see Foucault, "My Body, This Paper, This Fire").

8 “... la pensée autonome qui découvre par ses propres forces des relations intelligibles entre des essences déjà existantes."

${ }^{9}$ This name is derived from a passage in Descartes' letter to Hyperaspistes, dated August 1641, where he states that if an infant's mind were "released from the prison of the body," it would discover innate ideas within it (III 424).

${ }^{10}$ Descartes' conjectures on the "prison of the body" are especially problematic given that they are not sustained by his Passions of the Soul. 
${ }^{11}$ See also Descartes' letter to Voetius, dated May 1643, where he contrasts the use of reason for "education" with scholastic "learning," through which students "lose the use of their natural reason and put in its place an artificial and sophistical reason” (VIIIb: 43).

12 Harth discusses responses to Descartes from several now neglected seventeenth century "Cartésiennes": Anne de la Vigne, Marie Dupré, and Catherine Descartes (niece of René), as well as Princess Elisabeth of Bohemia (64-106).

${ }^{13}$ Note that this claim echoes Descartes' critique of scholastic artifice and, intentionally or not, suggests the "gallantry" that Poullain derides elsewhere (49; see also 69-72 for other passages that suggest a gallant discourse).

14 The editors source Aristotle's claim to Generation of Animals 737a27-28. The claim that women are imperfect men is attributed by Poullain to Philo, and by Beauvoir to Aquinas (Second Sex 5).

${ }^{15}$ Again, see Harth 64-106.

${ }^{16}$ See Poullain's On the Education of Ladies 227. Stuurman argues that the Passions of the Soul "gives us only a physiological explanation and a general taxonomy of the passions. The theory cannot explain why particular people are more strongly affected by some passions than by others" (87-88).

${ }^{17}$ It is also interesting to note that during his reconstruction of the Cartesian system in his On the Education of Ladies, Poullain follows the proof for the existence of the cogito with a proof for the existence of the body: "I concluded just now that I exist, I who think, because I act. There being a thing from which I cannot be separated which brings me pleasure and pain without any contribution on my part, and sometimes even despite myself, then this thing that I call my body must really exist" (178).

${ }^{18}$ See Sartre's later self-critique in "The Itinerary of a Thought" 33-34.

${ }^{19}$ Interestingly, for Beauvoir childhood plays a crucial role in the habituation of social roles, values, and prejudices. In The Ethics of Ambiguity, she writes that "Man's unhappiness, says Descartes, is due to his having first been a child" (35), but her reading of Descartes in this respect bears more similarities to Poullain, who challenged the reification and "inevitability" of social convention, than to Descartes, who wavered between faulting as the origin of prejudice and habit either social reification or the natural composition of the body itself. Beauvoir criticizes both the Freudian determination of penis envy from an anatomical lack (Second Sex 287) and (implicitly) Sartre's bizarre claim that a woman's existence "in the form of a hole" is first grasped in the infant's "ontological presentiment" of sexuality (Being and Nothingness 782), because childhood must also be historically situated.

${ }^{20}$ See, for instance, Beauvoir's discussion of the biblical myth of Eve's creation (Second Sex 15). 
21 Baillet, as Rodis-Lewis points out, "was attacked with the appearance of his Vie de $R$. Descartes, which was judged ridiculous for the importance granted to mere valets and women: 'There is no sex ... no condition, no social rank, no profession, whom Baillet does not honor by placing them in his work" (Rodis-Lewis xiii; the quotation is from Antoine Boschet).

\section{Works Cited}

Aristotle. Politics. The Basic Works of Aristotle. Ed. Richard McKeon. New York: The Modern Library, 2001. 1127-1316. All citations provide the Bekker numbers as reproduced in this translation.

Atherton, Margaret. "Cartesian Reason and Gendered Reason." A Mind of One's Own: Feminist Essays on Reason and Objectivity. Ed. Louise M. Antony and Charlotte Witt. Boulder, Co.: Westview Press, 1993. 19-34.

Badiou, Alain. Logics of Worlds. Trans. Alberto Toscano. New York: Continuum, 2009.

—. Manifesto For Philosophy. Trans. Norman Madarasz. Albany: SUNY Press, 1999.

Beauvoir, Simone de. The Ethics of Ambiguity. Trans. Bernard Frechtman. New York: Citadel Press, 1976.

- The Second Sex. Trans. Constance Borde and Sheila Malovany-Chevallier. New York: Vintage, 2009.

Bordo, Susan R. The Flight to Objectivity: Essays on Cartesiansism and Culture. Albany: SUNY Press, 1987.

Carriero, John. Between Two Worlds: A Reading of Descartes's Meditations. Princeton: Princeton University Press, 2009.

Césaire, Aimé. Discourse on Colonialism. Trans. Joan Pinkham. New York: Monthly Review Press, 2000.

Delon, Michel. “Cartésianisme(s) et féminisme(s).” Europe 56, no. 594 (October 1978): 73-86.

Descartes, René. The Philosophical Writings of Descartes. 3 Volumes. Ed. John Cottingham, et al. Cambridge: Cambridge University Press, 1984-1991. All citations give the Adam and Tannery pagination as reproduced in these translations. Volume 1 contains the Discourse on the Method and Principles of Philosophy, Volume 2 the Meditations, the Objections and Replies, and "The Search for Truth," and Volume 3 the correspondence. 
Foucault, Michel. "My Body, This Paper, This Fire." Aesthetics, Method, and Epistemology. Ed. James D. Faubion. New York: The New Press, 1998. 393-417.

Garber, Daniel. "Semel in vita: The Scientific Background to Descartes." Meditations. Essays on Descartes' Meditations. Ed. Amélie Oksenberg Rorty. Berkeley: University of California Press, 1986. 81-116.

Harth, Erica. Cartesian Women: Versions and Subversions of Rational Discourse in the Old Regime. Ithaca: Cornell University Press, 1992.

Heidegger, Martin. What is a Thing? Chicago: Henry Regnery Company, 1967.

Kail, Michel. "Beauvoir, Sartre, and the Problem of Alterity." Beauvoir and Sartre: The Riddle of Influence. Ed. Christine Daigle and Jacob Golomb. Bloomington: Indiana University Press, 2009. 143-159.

Marx, Karl. "Toward a Critique of Hegel's Philosophy of Right: Introduction." Selected Writings. Ed. Lawrence H. Simon. Indianapolis: Hackett Publishing, 1994. 27-39.

Negri, Antonio. Political Descartes: Reason, Ideology, and the Bourgeois Project. Trans. Matteo Mandarini and Alberto Toscano. London: Verso, 2007.

Poullain de la Barre, François. Three Cartesian Feminist Treatises. Trans. Vivien Bosley. Chicago: University of Chicago Press, 2002. All references to Poullain refer to this volume.

Rancière, Jacques. Disagreement: Politics and Philosophy. Trans. Julie Rose. Minneapolis: University of Minnesota Press, 1999.

- The Ignorant Schoolmaster. Trans. Kristin Ross. Stanford: Stanford University Press, 1991.

—. "L'actualité du Maître ignorant." Et tant pis pour les gens fatigues. Paris: Editions Amsterdam, 2009. 409-427.

- The Philosopher and His Poor. Ed. Andrew Parker. Durham: Duke University Press, 2003.

—. "Ten Theses on Politics." Dissensus: On Politics and Aesthetics. Trans. Steven Corcoran. London: Verso, 2010. 27-44.

Rodis-Lewis, Geneviève. Descartes: His Life and Thought. Trans. Jane Marie Todd. Ithaca, NY: Cornell University Press, 1998. 
Sartre, Jean-Paul. Being and Nothingness. Trans. Hazel Barnes. New York: Washington Square Press, 1992.

—. "The Itinerary of a Thought." Between Existentialism and Marxism. London: Verso, 2008. $33-64$.

—_. "La liberté cartésienne." Critiques littéraires (Situations, I). Paris: Gallimard, 1993. 289308.

Simons, Margaret A. Beauvoir and the Second Sex: Feminism, Race, and the Origins of Existentialism. Lanham: Rowman and Littlefield, 1999.

Stuurman, Siep. François Poulain de la Barre and the Invention of Modern Equality. Cambridge, Mass.: Harvard University Press, 2004.

Žižek, Slavoj. The Ticklish Subject. London: Verso, 1999. 